\title{
Use of kaolin as a potential low-cost adsorbent for the removal of reactive blue BF-
}

\section{G dye}

Uso de caulim como um potencial adsorvente de baixo custo para a remoção do corante azul reativo BF-5G

\section{Uso de caolín como adsorbente potencial de bajo costo para la eliminación del tinte azul reactivo}

BF-5G

\begin{abstract}
The objective of this work was to use kaolin as an adsorbent for synthetic effluent, based on the reactive blue dye BF5G. Several analytical techniques were used to investigate the material's crystallinity, morphology, specific surface area and fundamental functional group of kaolin. In sequence, different $\mathrm{pH}$ values were studied using a finite bath system. In investigating the influence of $\mathrm{pH}$, the adsorbent used showed superior performance at a $\mathrm{pH}$ value equal to 1. From this optimal value, kinetic studies were carried out with the ideal conditions of $\mathrm{pH}$, concentration and adsorbents $\left(\mathrm{pH}=1, \mathrm{C}_{0}=50 \mathrm{mg} / \mathrm{L}\right.$ and kaolin used as adsorbent). The adsorption percentage is maximum at $\mathrm{pH} 1$ and decreases with the basic strength of the dye solution.
\end{abstract}

Keywords: Low-cost adsorbent; Adsorption; Reactive dyes; Textile wastewater.

\section{Resumo}

O objetivo deste trabalho foi utilizar o caulim como adsorvente de efluente sintético, à base de corante azul reativo BF-5G. Várias técnicas analíticas foram utilizadas para investigar a cristalinidade do material, morfologia, área superficial específica e grupo funcional fundamental do caulim. Em sequência, diferentes valores de $\mathrm{pH}$ foram estudados utilizando um sistema de banho finito. $\mathrm{Na}$ investigação da influência do $\mathrm{pH}$, o adsorvente utilizado apresentou desempenho superior no valor de $\mathrm{pH}$ igual a 1. A partir desse valor ótimo, estudos cinéticos foram desenvolvidos com as condições ideais de $\mathrm{pH}$, concentração e adsorventes $\left(\mathrm{pH}=1, \mathrm{C}_{0}=50 \mathrm{mg} / \mathrm{L}\right.$ e caulim usado como adsorvente). A percentagem de adsorção é máxima em pH 1 e diminui com a força básica da solução corante. Palavras-chave: Adsorvente de baixo custo; Adsorção; Corantes reativos; Águas residuais têxteis.

\section{Resumen}

El objetivo de este trabajo fue utilizar caolín como adsorbente de efluentes sintéticos, a partir del colorante azul reactivo BF-5G. Se utilizaron varias técnicas analíticas para investigar la cristalinidad, morfología, superficie específica y grupo funcional fundamental del caolín del material. En secuencia, se estudiaron diferentes valores de $\mathrm{pH}$ utilizando un sistema de baño finito. Al investigar la influencia del pH, el adsorbente utilizado mostró un desempeño superior a un valor de $\mathrm{pH}$ igual a 1. A partir de este valor óptimo, se realizaron estudios cinéticos con las condiciones ideales de $\mathrm{pH}$, concentración y adsorbentes $\left(\mathrm{pH}=1, \mathrm{C}_{0}=50 \mathrm{mg} / \mathrm{L}\right.$ y caolín utilizado como adsorbente). El porcentaje de adsorción es máximo a pH 1 y disminuye con la concentración básica de la solución de tinte.

Palabras clave: Adsorbente de bajo costo; Adsorción; Tintes reactivos; Aguas residuales textiles. 


\section{Introduction}

Environmental pollution is a major threat to human life. Among the different types of pollution, wastewater flow is a major problem due to the large amount of water used in our daily life. Wastewater printing and dyeing is a considerable source of environmental contamination and discoloration is the main problem. As a traditional organic dye, the presence of methylene blue (MB) in discharged water is hazardous to humans (Gao et al., 2009; Medri et al., 2020).

The methylene blue dye (MB) is widely used in the textile industry to dye cotton, wood and leather, in addition to the pharmaceutical industries. MB causes harmful effects to human health, such as nausea, vomiting, increased heart rate and eye / skin irritation. The discharge of untreated synthetic dyes in aqueous media is one of the most important environmental problems due to its risks to aquatic life and human health (Jawad et al., 2020; Meigoli Boushehrian, Esmaeili \& Foroutan, 2020).

Dyes are widely classified as anionic, cationic, nonionic and zwitterionic, depending on the ionic charge in the dye molecules. Cationic dyes are more toxic than anionic dyes (Nandi, Goswami, \& Purkait, 2009; Hao, Kim, \& Chiang, 2000).

Wastewater effluents contain synthetic dyes which may cause a potential hazard to the environment. Due to the environmental and health concerns associated with the wastewater effluents, many different separation techniques have been used in the removal of dyes from aqueous solutions. The dye removal techniques are physical, Chemical and and Biological methods.

Therefore, adsorption technology has become an ideal method for the removal of toxic contaminants from wastewater due to its simplicity, high efficiency, economical value and environmental friendliness (Zhou et al., 2019; Mustapha et al., 2021).

It is one of the most powerful methods due to its easy operation, non-susceptibility to pollutants, reuse, and less waste production (Jawad et al., 2020; Jawad, Abdulhameed \& Mastuli, 2020).

It is well-know that adsorption has received important attention due to its high capacity in the removal of dyes. Although the big number of adsorbents used in adsorption methods, activated carbon is the one that has been most generally used for effluents treatment purposes all over the world (Pereira et al., 2003). In spite of that cost-prohibitive associated with the treatment processes limit situation the use of activated carbon (Foo \& Hameed, 2010). For this reason, divers studies have been carried out in order to find out effective and low cost adsorbents. Various adsorbents can be used for removing dyes, such as clays (Barbosa et al., 2019; Rocha et al., 2016), molecular sieve (De Paula et al., 2020), agricultural wastes (Salleh et al., 2011; Singh et al., 2017).

Among these materials, raw kaolin is relatively inexpensive and has a higher adsorption capacity (Tang et al., 2009). Kaolin is one of the well-known low-cost raw clays due to its good adsorption properties (Vimonses et al., 2009; Zhu et al., 2010).

Kaolin is a clay predominantly composed by kaolinite $\left(\mathrm{Al}_{2} \mathrm{Si}_{2} \mathrm{O}_{5}(\mathrm{OH})_{4}\right)$, which has been widely used in a several of technological applications (Castellano et al., 2010; Ajayi et al., 2010).

Due to the low-cost and large abundance, the use of clays like kaolin becomes the adsorption process an attractive and promising technology. There are several works in the literature disclosing the removal of different dyes in kaolin, no studies were found reporting the application of a kaolin from the region Caiçara, state of Rio Grande do Norte, Brazil for the removal of reactive blue dye $\mathrm{BF}-5 \mathrm{G}$.

The aim of the present work was to investigate the ability of Brazil kaolin as a new low-cost and efficient adsorbent for removal of reactive blue BF-5G dye from aqueous environment. 


\section{Methodology}

\subsection{Materials and chemical}

Natural kaolin was collected from local area, Caiçara, Rio Grande do Norte, Brazil. It was sieved according to the Brazilian ABNT standard No 200 (0.074 mm) sieve.

Synthetic solution was prepared from Reactive blue BF-5G dye supplied by Texpal Química Ltda, Valinhos, São Paulo, Brazil. All laboratory grade reagents, sodium hydroxide $(\mathrm{NaOH})$, Hydrochloric acid $(\mathrm{HCl})$ and distilled water was used without any purification.

\subsection{Characterization}

\subsubsection{X-ray Diffraction (XRD)}

Powder diffraction patterns were measured on a Shimadzu XRD 6000. The operational conditions were: Copper K radiation at $40 \mathrm{kV} / 30 \mathrm{~mA}$, goniometer velocity of $2 \%$ min with a step of $0.02 \mathrm{o}$ over 2 range from $2^{\circ}$ to $50^{\circ}$.

\subsubsection{Nitrogen adsorption-desorption}

Isothermal gas adsorption-desorption of $\mathrm{N} 2$ at $77 \mathrm{~K}$. The values of the average pore diameter ( $\left.\mathrm{Vp}_{\text {total }}\right)$ and surface area $\left(\mathrm{S}_{\mathrm{BET}}\right)$ were obtained by the proposed method (BET), in a Micrometrics ASAP 2020 equipment.

\subsubsection{Scanning electron microscopy (SEM)}

A small amount of powder was deposited in an aluminum holder, sprayed with gold and images were obtained using a Shimadzu SSX-550 electron microscope.

\subsubsection{Infrared (IR)}

IR spectra of samples were obtained using Bomem, MB-102. The samples were submitted to a physical treatment in accordance with the $\mathrm{KBr}$ method, which consists in mixing $0.007 \mathrm{~g}$ of the sample and $0.1 \mathrm{~g}$ of $\mathrm{KBr}$, grinding and pressing the solid mixture to 5 ton during $30 \mathrm{~s}$ in order to form a pastille that allows the passage of light. The IR spectra were obtained in the range of 500-4000 cm-1 at $2 \mathrm{~cm}-1$ resolution.

\subsection{Batch Adsorption Experiments}

\subsubsection{Influence of $\mathrm{pH}$}

To carry out the experiments, kaolin was used as an adsorbent. The adsorbate used was an aqueous solution of reactive Blue dye BF - 5G supplied by TEXPAL.

For the analysis of the $\mathrm{pH}$ in the removal of the dye reactive $\mathrm{Blue} \mathrm{BF}-5 \mathrm{G}$, dilutions were made from a solution at $1000 \mathrm{mg} / \mathrm{l}$ of the dye. Then, the initial solution was diluted to a concentration of $50 \mathrm{mg} / \mathrm{l}$. The $\mathrm{pH}$ adjustment was made with 1.0 M sodium hydroxide and 3.0 M hydrochloric acid.

In the tests, previously identified erlenmeyers were used, containing $0.5 \mathrm{~g}$ of the adsorbent with $50 \mathrm{ml}$ of the dye solution at a concentration of $50 \mathrm{mg} / \mathrm{l}$. For each erlenmeyer flask, the $\mathrm{pH}$ was corrected in accordance with its identification. The samples were kept under agitation, at a temperature of $25^{\circ} \mathrm{C}$, in a TE- 420 Tecnal shaker, at $200 \mathrm{rpm}$ for 3 hours.

After this time, the samples were filtered aiming to remove the solid matter and the filtrate taken to visible spectrophotometric analysis. The dye concentration after the finite bath tests was measured in a UV-Visible Spectrophotometer, in order to assess the remaining dye concentration. 
The choice of the optimal $\mathrm{pH}$ was made from a test performed on the samples, with $\mathrm{pH}$ variation. Figure 1 shows a photo of the results of the influence of kaolin $\mathrm{pH}$.

Figure 1. Samples after adsorption (kaolin).

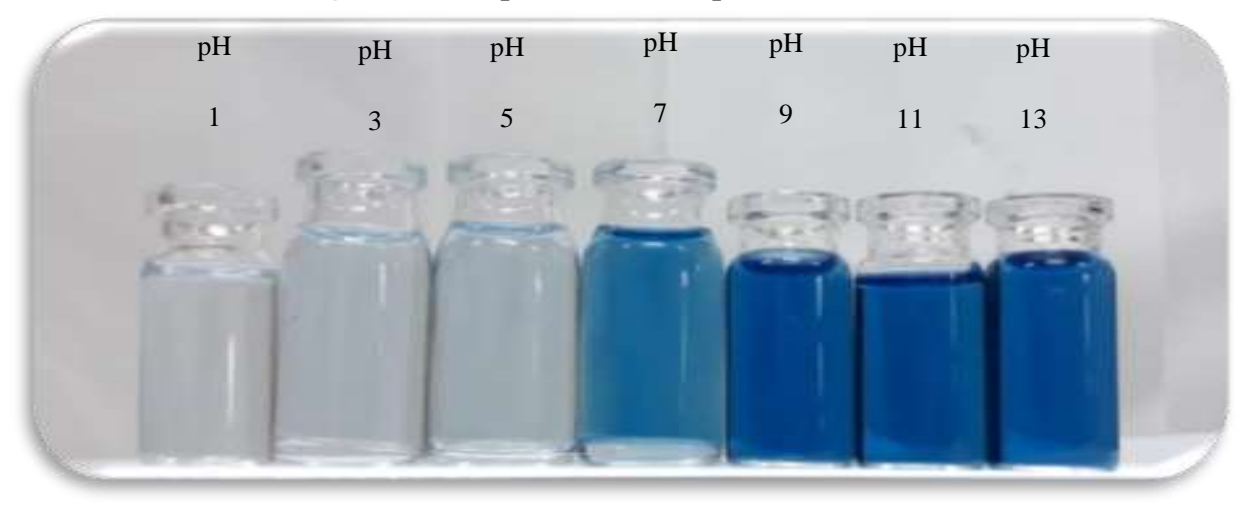

Source: Authors.

Figure 1 show the difference in color between the containers containing the filtrates at different $\mathrm{pHs}$, which shows that the adsorbents used have a higher adsorption effect on strongly acidic media.

From the photo presented in Figure 1, it can be seen that at $\mathrm{pH}$ 1, there was a greater removal.

The total dye removal percentage (Rem $(\%)$ ) as well as the removal capacity dye at equilibrium ( $\mathrm{q}_{\mathrm{eq}}$ ) can be obtained through Equations 1 and 2, respectively:

$$
\text { \%Rem }=\left(\frac{C_{D}-C}{C_{0}}\right)-100
$$

where: \% Rem is the total percentage of dye removal; $\mathrm{C}_{0}$ is the concentration of the initial solution in $\mathrm{mg} / \mathrm{L}$; $\mathrm{C}$ is the concentration of the final solution in $\mathrm{mg} / \mathrm{L}$.

$$
\mathrm{q}_{\mathrm{eq}}=\frac{\mathrm{V}}{\mathrm{m}} \times\left(\mathrm{c}_{00}-\mathrm{c}_{\text {eqq }}\right)
$$

Where: $\mathrm{q}_{\mathrm{eq}}$ is the removal capacity dye at equilibrium ( $\mathrm{mg}$ of dye/g of adsorbent), $\mathrm{C}_{0}$ the initial concentration of dye (mg/L), Ceq the final concentration of dye ion $(\mathrm{mg} / \mathrm{L}), \mathrm{V}$ the volume of the adsorbate $(\mathrm{L})$, and $\mathrm{m}$ the mass of adsorbent $(\mathrm{g})$.

\subsection{Kinetic Study}

pH was adjusted to 1 and Kaolin mass was $0.5 \mathrm{~g}$. The kinetic test was performed using a finite bath system, in which the $\mathrm{pH}=1$ and agitation $=200 \mathrm{rpm}$ conditions were determined by the finite bath test that provided the best percentage of removal of dye by this kaolin. For the kinetic study, samples from the solution were collected at different time intervals between 1 to 6 hours, taking care that the volume withdrawn did not exceed $8 \%$ of the total volume. Afterwards, the solutions were filtered and analyzed for residual dye concentration with a UV-Vis spectrophotometer UV-VIS 1600 (Pro-Analysis).

\section{Results and Discussion}

According to the X-ray diffractograms, it can observe that kaolin (Figure 2) consists essentially of kaolinite clay mineral. The presence of kaolinite in kaolin was confirmed by characteristic reflections at $2 \theta=12.41,20.21$ (multiple reflections) and $25.49^{\circ}$, the first and last intense and well defined (Moore \& Reynolds, 1989; Ahmed et al., 2016). Other clay minerals such as quartz $\left(\mathrm{SiO}_{2}\right.$ - JCPDFWIN ICDD 87-2096) and illite $\left(\mathrm{KAl}_{2} \mathrm{Si}_{3} \mathrm{AlO}_{10}(\mathrm{OH})_{2}\right.$ - JCPDFWIN ICDD 02-0056) are 
also observed, but with less intense peaks when compared to kaolinite peaks.

The small reflection at $26.5^{\circ} 2 \theta$ showed the presence of traces of quartz and $8.86^{\circ}$ of the illite. These findings are consistent with other previously reported work (Nandi et al., 2009; Caponi et al., 2017). Figure 2 show a picture of the results of the influence of the $\mathrm{pH}$ of kaolin.

Figure 2. XRD patterns of the kaolin.

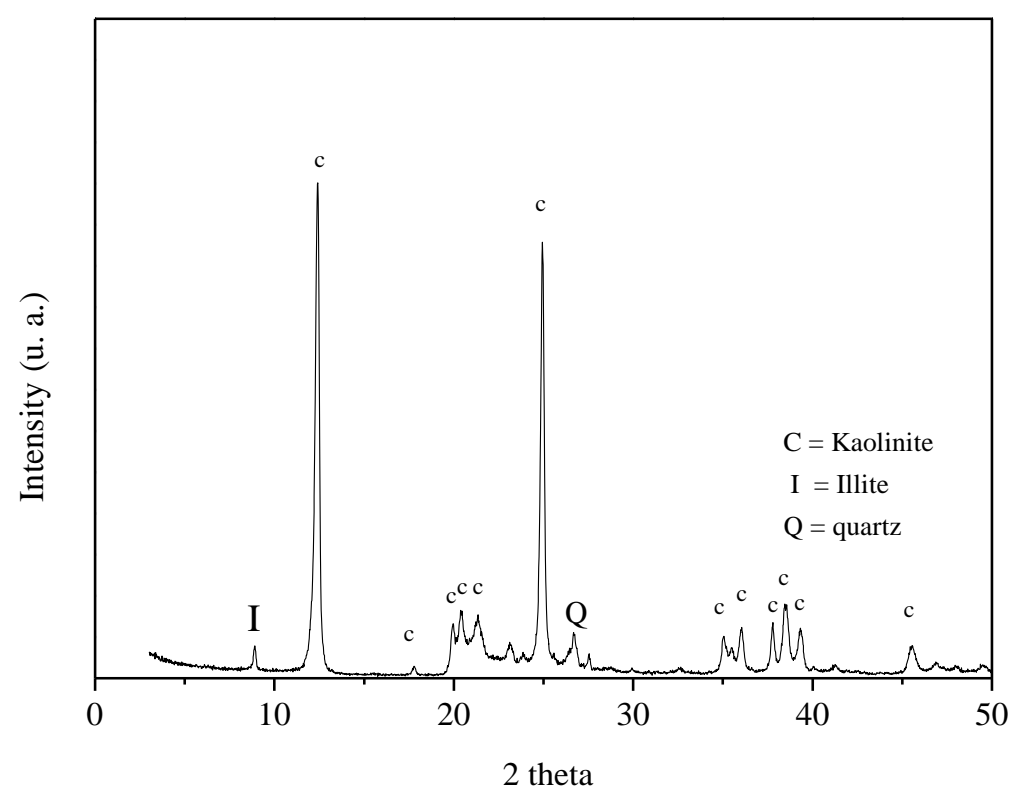

Source: Authors.

The chemical compositions of the clays are listed in Table 1. The samples contain 52.07 wt.\% $\mathrm{SiO}_{2}$ and 45.89 wt.\% $\mathrm{Al}_{2} \mathrm{O}_{3}, 0.71 \mathrm{wt} . \% \mathrm{Fe}_{2} \mathrm{O}_{3}$ and small abundances of alcalis and alcaline earth elements (2 wt.\%). Commonly, a pure kaolinite is made up of 46.5 wt. \% of $\mathrm{SiO}_{2}$ and $39.5 \mathrm{wt} . \%$ of $\mathrm{Al}_{2} \mathrm{O}_{3}$. Then, the composition of the kaolin used in this work was close to a kaolinite mineral with high purity degree (Nallis et al., 2013).

Table 1. Composition of the kaolin sample.

\begin{tabular}{|l|l|l|l|l|}
\hline Sample & $\begin{array}{l}\mathrm{SiO}_{2} \\
(\text { wt.\% })\end{array}$ & $\begin{array}{l}\mathrm{Al}_{2} \mathrm{O}_{3} \\
\text { (wt.\%) }\end{array}$ & $\begin{array}{l}\mathrm{Fe}_{2} \mathrm{O}_{3} \\
\text { (wt.\%) }\end{array}$ & $\begin{array}{l}\text { Impurities } \\
\text { (wt.\%) }\end{array}$ \\
\hline Kaolin & 52.07 & 45.89 & 0.71 & $\sim 2$ \\
\hline
\end{tabular}

Source: Authors.

A representative SEM image of kaolin is given in Figure 3. As regards the surface morphology of kaolin, SEM data demonstrate that this kaolin sample presents irregular shape, rough surface, and flaky-shaped particles. These variations may be associated with the origin of the deposit and the degree of crystallinity of the mineral. Through micrographs, we can observe clusters of micrometric particles formed by stacking crystals that appear in laminar form, of variable sizes with irregular hexagon-like edges, that is, plates of pseudo-hexagonal morphology, typical characteristic of the main kaolinite crystals constituent of kaolin. 
Figure 3. SEM image of the kaolin.

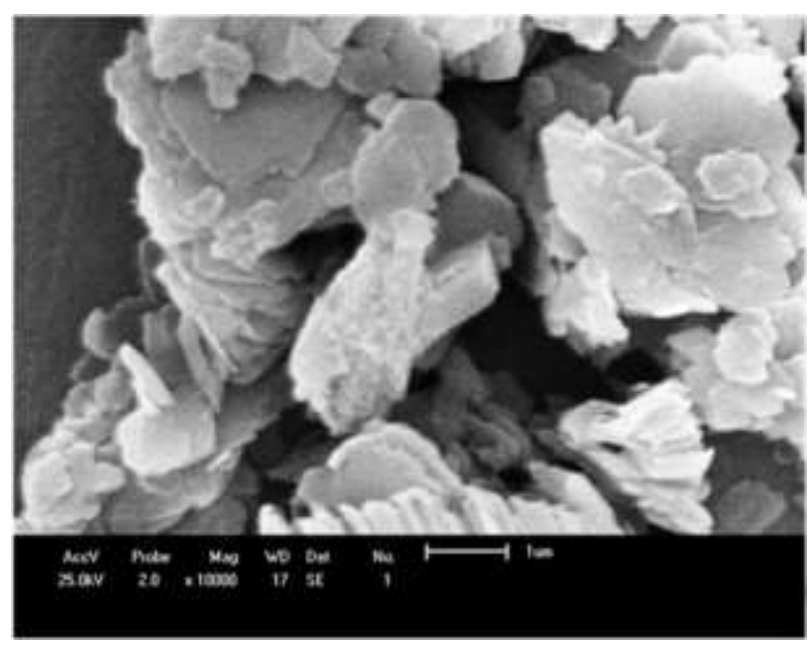

Source: Authors.

Isothermal gas adsorption-desorption of $\mathrm{N}_{2}$ at $77 \mathrm{~K}$ showed that the kaolin (Table 2) presented a specific surface area of $5 \mathrm{~m} 2 / \mathrm{g}$ and pore volume of $0.032 \mathrm{~cm} 3 / \mathrm{g}$. Such values are similar to those given by authors (Wang et al., 2011; Zhang et al., 2010).

Table 2. Textural analysis of the kaolin.

\begin{tabular}{|l|l|l|}
\hline Sample & $\mathrm{S}_{\text {BET }}\left(\mathrm{m}^{2} / \mathrm{g}\right)$ & $\mathrm{Vp}_{\text {total }}\left(\mathrm{cm}^{3} / \mathrm{g}\right)$ \\
\hline Kaolin & 5 & 0.032 \\
\hline
\end{tabular}

Source: Authors.

The $\mathrm{N}_{2}$ adsorption-desorption isotherms of kaolin adsorbent is exhibited in Figure 4.

Figure 4. $\mathrm{N}_{2}$ adsorption-desorption isotherms of kaolin.

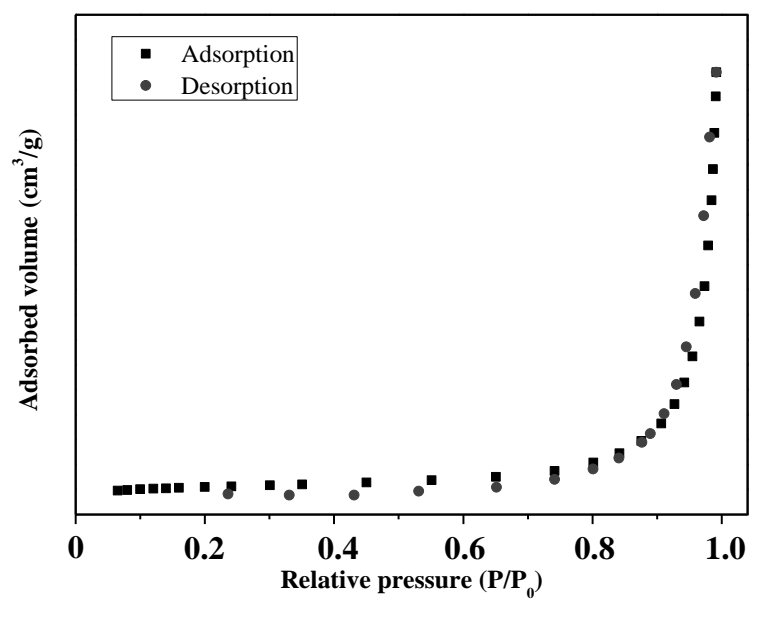

Source: Authors.

As shown in Figure 4, the $\mathrm{N}_{2}$ adsorption-desorption isotherms of adsorbent can be classified as type IV, with type- $\mathrm{H}_{3}$ hysteresis behavior, which are indicative of predominantly mesoporous material.

Figure 5 illustrate a typical infrared spectra of kaolin. The IR spectrum showed (Figure 5) bands between $3607 \mathrm{~cm}^{-1}$ 
and $3680 \mathrm{~cm}^{-1}$, corresponding respectively to the $\mathrm{OH}$ stretching vibrations of the surface and inner Al-OH groups of kaolinite. The bands at $989 \mathrm{~cm}^{-1}$ to $1110 \mathrm{~cm}^{-1}$ can be ascribed to the stretching vibrations of the Si-O-Si of kaolinite or quartz; and that at $798 \mathrm{~cm}^{-1}$ to OH deformation linked to Al (Russel \& Fraser, 1994; Frost \& Johansson, 1998).

Figure 5. Infrared spectra of kaolin.

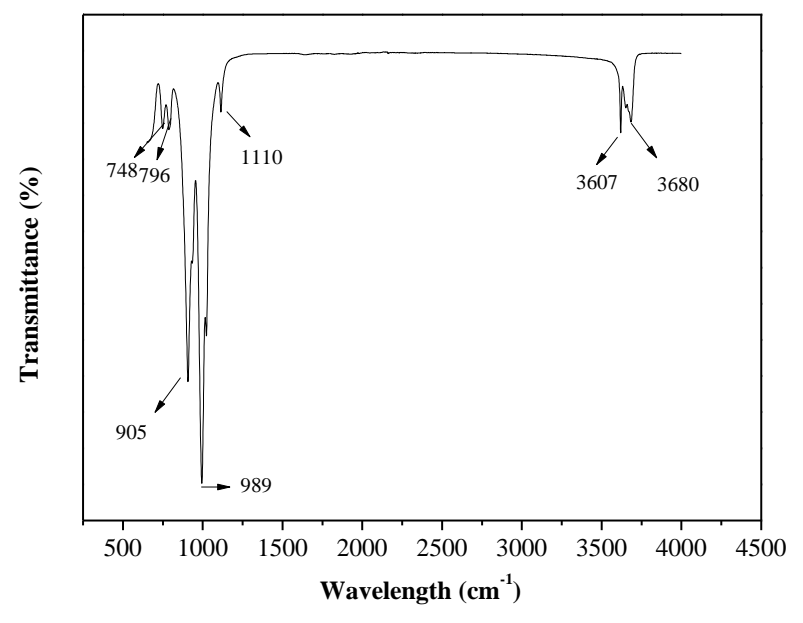

Source: Authors.

\subsection{Influence of pH}

The influence of $\mathrm{pH}$ on the dye adsorption onto kaolin was studied while the dye concentration, shaking time and amount of kaolin were fixed at $50 \mathrm{mg} / \mathrm{L}, 200 \mathrm{rpm}$ and $0.5 \mathrm{~g}$ respectively. The variation of reactive blue BF-5G dye adsorption on kaolin over a pH range of $1-13$ is shown in Figure 6.

The result for kaolin reveals that the adsorption of the dye-kaolin remains almost constant to $\mathrm{pH} 6$, decrease from 60 $\%$ to $10 \%$ with a increase in $\mathrm{pH}$ of the solution from 6 to 14 .

The authors observed a removal of $10.12 \%$ of the dye using zeolite $\mathrm{NaY}$ (conventional method) and a removal of 52.60 of the dye using zeolite $\mathrm{NaY}$ (modified with CTMABr), showing a positive effect of addition of surfactant, during research carried out on the removal of the reactive blue dye BF-5G using zeolite NaY modified with cetyltrimethylammonium bromide (Rodrigues et al., 2018).

The authors analyzing the synthesis of the metal-organic structure ZIF-8 and application in the removal of reactive blue dye BF-5G, it was observed that the said metal-organic material exhibited excellent removal capacity and high removal percentages. This study showed the important potential of the metal-organic structure as an adsorbent in the removal of reactive dyes, showing that it is very promising in the treatment of industrial effluents (Rodrigues et al., 2018).

The authors studied batch adsorption of bifunctional reactive blue 5G dye on commercial activated carbon, observed that activated carbon had a maximum adsorption capacity of $2.36 \mathrm{mg} / \mathrm{g}$, showing itself to be a good adsorbent in this study system, as satisfactory values of percentage of dye removal (71 \%) were obtained (Silva et al., 2019).

The authors studied adsorption of the reactive blue BF-5G dye in zeolites: influence of $\mathrm{pH}$. Observed that the adsorption tests varying the $\mathrm{pH}$, the zeolites used showed a higher performance in $\mathrm{pH}$ value equal to 1 (Barbosa et al., 2019).

The results obtained for the removal capacity of the reactive blue are presented in Table 3 . 
Figure 6. Effect of $\mathrm{pH}$ on the adsorption of Reactive blue BF-5G dye on to kaolin.

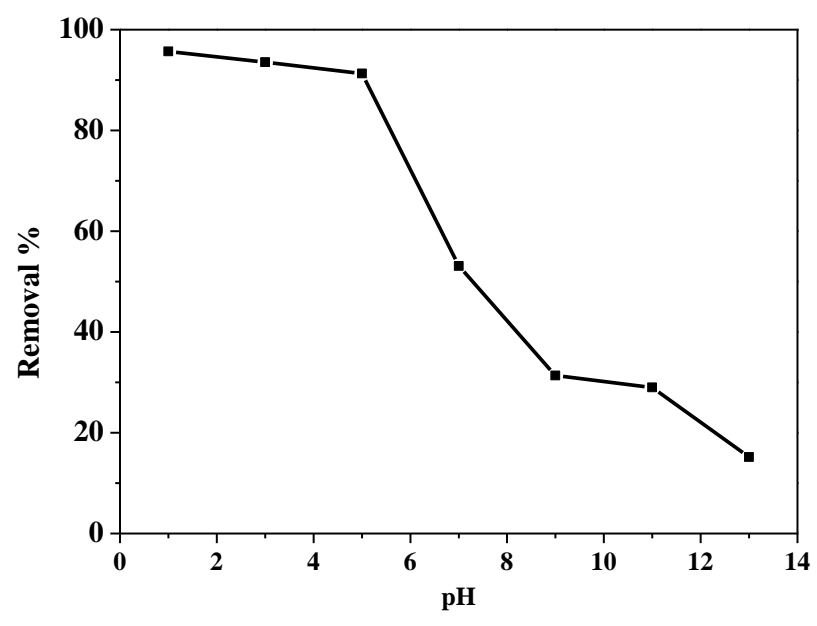

Source: Authors.

Table 3. Results obtained from the removal of the reactive blue BF-5G dye.

\begin{tabular}{|l|l|l|l|}
\hline Test & mass $(\mathrm{g})$ & $\mathrm{pH}$ & $\mathrm{q}_{\text {eq }}(\mathrm{mg} / \mathrm{g})$ \\
\hline 1 & 0.5 & 1 & 4.90 \\
\hline 2 & 0.5 & 3 & 4.80 \\
\hline 3 & 0.5 & 5 & 4.68 \\
\hline 4 & 0.5 & 7 & 2.72 \\
\hline 5 & 0.5 & 9 & 1.60 \\
\hline 6 & 0.5 & 11 & 1.48 \\
\hline 7 & 0.5 & 13 & 0.77 \\
\hline
\end{tabular}

Source: Authors.

Some observations can be highlighted:

1. At acid $\mathrm{pH}$, percentage removal values are greater than $50 \%$; while at $\mathrm{pH} 1$ (strongly acid) the removal percentage was $95.69 \%$ for kaolin removal capacity $\left(\mathrm{q}_{\mathrm{eq}}\right)$ of approximately $4.90 \mathrm{mg} / \mathrm{g}$.

2. At neutral $\mathrm{pH}$, the percentage removal values are greater than $9 \%$ being equivalent to $2.72 \mathrm{mg} / \mathrm{g}$ for $\mathrm{kaolin}$ values for removal capacities (qeq).

3. At basic $\mathrm{pH}$, the value is over $13 \%$. Where the highest percentage of removal in the basic medium was 31.34 $\%$ for kaolin. With removal capacities (qeq) ranging from $0.77-1.60 \mathrm{mg} / \mathrm{g}$.

4. The best removal was found to be $95.69 \%$ at $\mathrm{pH} 1$ for kaolin, where a removal capacity $\left(\mathrm{q}_{\mathrm{eq}}\right)$ of approximately $4.90 \mathrm{mg} / \mathrm{g}$ was obtained.

The literature shows that the adsorption process depends on several factors, such as the structure of the adsorbent and the adsorbate, and also depends on the experimental conditions, where the $\mathrm{pH}$ of the medium stands out. The $\mathrm{pH}$ of a solution is an important control parameter in the adsorption process and this parameter affects the surface charge of adsorbents as well as the degree of ionization of different pollutants. The variation in the $\mathrm{pH}$ value affects the adsorption process by the dissociation of functional groups at the active sites of the adsorbent surface. Consequently, this leads to a change in the reaction and equilibrium characteristics of the adsorption process (Mall et al., 2006). 


\subsection{Effect of contact time}

The adsorption kinetics of kaolin is indicated in Figure 7. It can be seen from the Figure 7 that the maximum amount of dye adsorption taking place within the contact time of $5 \mathrm{~min}$ and becomes constant after that. This indicates that the rate of adsorption is very fast. Data has been taken up-to $360 \mathrm{~min}$ of operation which close to attain equilibrium. After that no significant change in the extent of adsorption is observed.

Figure 7. Adsorption kinetics of kaolin.

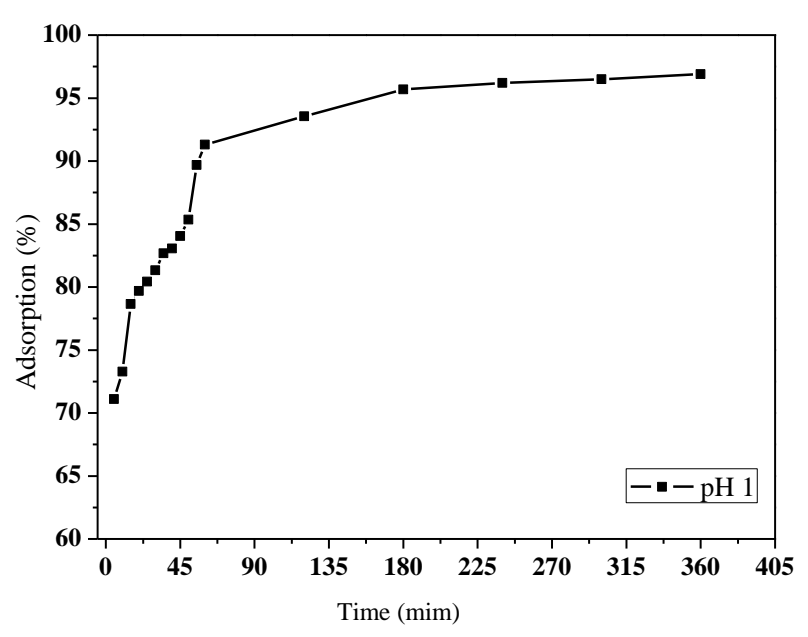

Source: Authors.

In order to evaluate the adsorption kinetics, the kinetic data of the adsorption of reactive blue BF-5G were adjusted in the models of pseudo-first order and pseudo-second order.

Table 4 shows the kinetic parameters of the pseudo-first order and pseudo-second order models. The linearization of the data to the chosen models is shown in Figures 8 and 9. For the pseudo-first order model, the values of qe, lime and $\mathrm{k}_{1}$ were calculated by intercepting and tilting the line of the graphs in Figure 8. In the pseudo-first model second order the values of qe, cal and $k_{2}$ were obtained from the slope and intercept of the line of the graphs in Figure 9.

The quantitative evaluation of the models was performed by comparing the correlation coefficients $\left(\mathrm{R}^{2}\right)$ and the sum of squares of errors (SSE). The values of $R^{2}$ in the pseudo-second order model were the closest to 1 , with $R^{2}>0.99$, while the other model, showed a value of $\mathrm{R}^{2}<0.89$. In addition, the lowest SSE values were presented using the pseudo-second order model. The values of qe, lime estimated by the model of pseudo-second order agreed with the values obtained experimentally qe, exp, while the values of qe, lime of the model of pseudo-first order did not present results compatible with the values obtained experimentally qe, exp. In view of the above, the adsorption kinetics of reactive blue BF-5G dye in kaolin was better adjusted to the pseudo-second order kinetic model.

The fact that the pseudo-second order model is the best model for adjusting the kinetic adsorption data of the reactive blue BF-5G dye in kaolin, implies that, based on its assumption, the adsorption of this dye in kaolin is due to chemisorption, where the interaction between the adsorbate and the adsorbent takes place through ionic and/or covalent bonds with the formation of a monolayer (Zhou et al., 2015). 
Figure 8. Linear adjustment of the pseudo-first order kinetic model for adsorption reactive blue BF-5G dye.

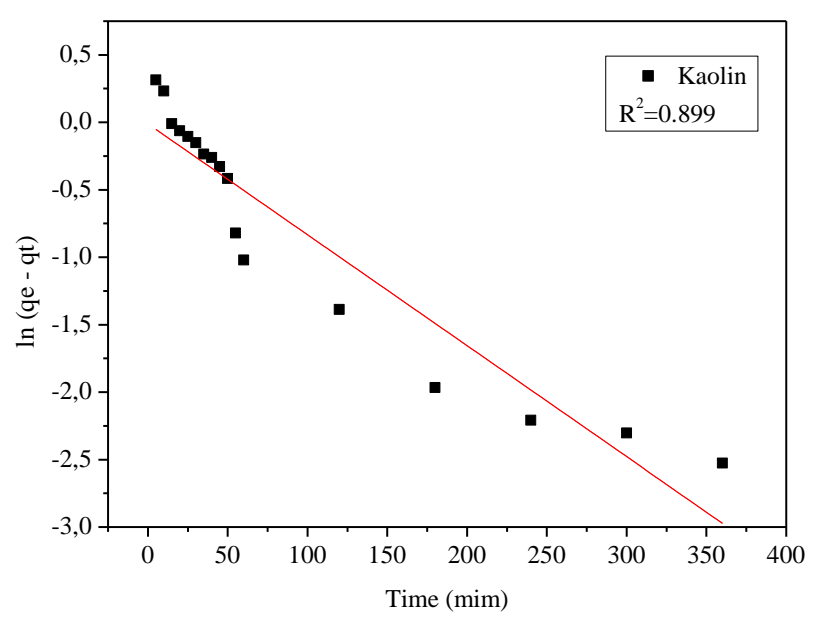

Source: Authors.

Figure 9. Linear adjustment of the pseudo-second order kinetic model for adsorption reactive blue BF-5G dye.

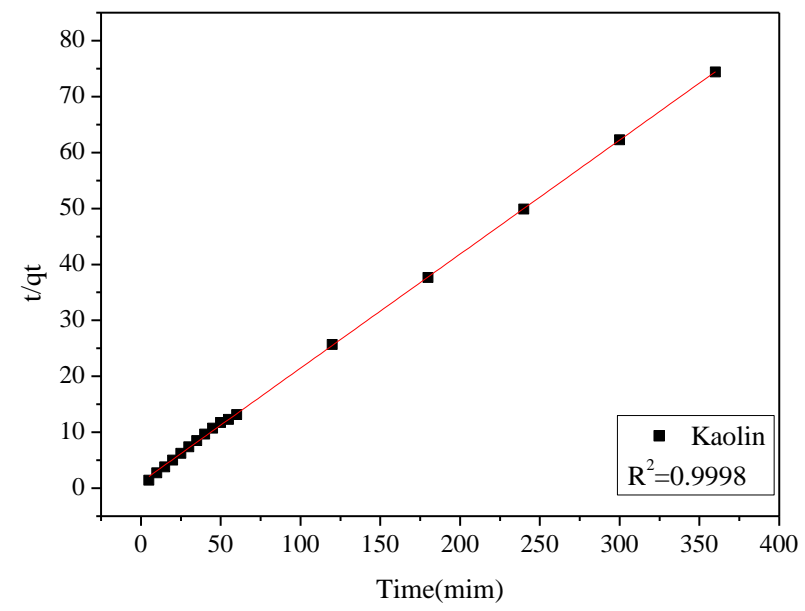

Source: Authors. 
Table 4. Kinetic parameters of pseudo-first order, pseudo-second order for reactive blue BF-5G dye adsorption.

\begin{tabular}{|l|l|}
\hline & Sample \\
\hline Kinetic model & Kaolin \\
\hline Pseudo-first-order model & \\
\hline $\mathrm{q}_{\mathrm{e}, \mathrm{exp}}\left(\mathrm{mg} \cdot \mathrm{g}^{-1}\right)$ & 96.37 \\
\hline $\mathrm{q}_{\mathrm{e}, \mathrm{cal}}\left(\mathrm{mg} \cdot \mathrm{g}^{-1}\right)$ & 87.65 \\
\hline $\mathrm{k}_{1}\left(\mathrm{~min}^{-1}\right)$ & 0.260 \\
\hline $\mathrm{R}^{2}$ & 0.8990 \\
\hline $\mathrm{SSE}$ & 0.0970 \\
\hline Pseudo-second-order model & \\
\hline $\mathrm{q}_{\mathrm{e}, \mathrm{exp}}\left(\mathrm{mg}_{\mathrm{g}} \mathrm{g}^{-1}\right)$ & 92.81 \\
\hline $\mathrm{k}_{1}\left(\mathrm{~min}^{-1}\right)$ & 0.004 \\
\hline $\mathrm{R}^{2}$ & 0.9989 \\
\hline $\mathrm{SSE}$ & 0.0015 \\
\hline
\end{tabular}

Source: Authors.

\section{Conclusion}

In this study, removal of dye is investigated using kaolin.

Kaolin deposits have been reported in different parts of the country. In the present study, kaolin was selected as local, cheaper and readily available adsorbent for reactive blue dye removal of aqueous solutions.

In the adsorption tests varying the $\mathrm{pH}$, the adsorbents used presented higher performance in $\mathrm{pH}$ value of 1 .

The present study represents the development of suitable strategies to prepare adsorbents for current application in the removal of dyes, as well as future applications in the release of drugs and heavy metals.

\section{Acknowledgments}

The authors gratefully acknowledge to the Petrobras, CAPES (Coordenação de Aperfeiçoamento de Pessoal de Nível Superior) and CNPq (Conselho Nacional de Desenvolvimento e Tecnológico).

\section{References}

Ahmed, K., Rehman, F., Pires, C. T. G. V. M. T., Rahim, A., Santos, A. L., \& Airold, C. (2016). Aluminum doped mesoporous silica SBA-15 for the removal of remazol yellow dye from water. Microporous and Mesoporous Materials, 236, 167-175. https://doi.org/10.1016/j.micromeso.2016.08.040

Ajayi, A. O., Atta, A. Y., Aderemi B. O. \& Adefila S. S. (2010). Novel Method of Metakaolin Dealumination -Preliminary Investigation. Journal of Applied Sciences Research, 6 (10), 1539-1546.

Barbosa, A. dos S., \& Rodrigues, M. G. F. (2019). Adsorção do corante azul reativo BF-5G em zeólitas: influência do pH. In: I Congresso Internacional de Meio Ambiente e Sociedade e III Congresso Internacional da Diversidade do Semiárido - I CONIMAS e III CONIDIS, 2019, Campina Grande. I Congresso Internacional de Meio Ambiente e Sociedade e III Congresso Internacional da Diversidade do Semiárido - I CONIMAS e III CONIDIS.

Barbosa, A. S., Monteiro, G. S., Rocha, L. N., Lima, E. G., \& Rodrigues, M. G. (2019). Remoção do Corante Reativo vermelho por adsorção utilizando argilas branca e vermelha. Revista Gestão e Sustentabilidade Ambiental, 8, 539-561. http://dx.doi.org/10.19177/rgsa.v8e22019539-561

Caponi, N., Collazzo, G. C., Jahn, S. L., Dotto, G. L., Mazutti, M. A., \& Foletto, E. L. (2017). Use of Brazilian kaolin as a potential low-cost adsorbent for the removal of malachite green from colored effluents. Journal of Materials Research, 20, 14-22. https://doi.org/10.1590/1980-5373-MR-2016-0673

Castellano, M., Turturro, A., Riani, P., Montanari, T., Finocchio, E., Ramis, G., \& Busca G. (2010). Bulk and surface properties of commercial kaolins. Applied Clay Science, 48 (3), 446- 454. https://doi.org/10.1016/j.clay.2010.02.002 
De Paula, L. R. N., De Paula, G. M., Santos, T. S., Clericuzi, G., \& Rodrigues, M. G. F. (2020). Synthesis and application of MCM-41 molecular sieve for removal of reactive dyes. Materials Science Forum.

Foo, K. Y., \& Hameed, B. H. (2010). An overview of dye removal via activated carbono adsorption process. Desalination and Water Treatment, $19,255-274$. https://doi.org/10.5004/dwt.2010.1214

Frost, R. L., \& Johansson, U. (1998). Combination Bands in the Infrared Spectroscopy of Kaolins-A Drift Spectroscopic Study. Clays and Clay Minerals, 46, 466-477. https://doi.org/10.1346/CCMN.1998.0460411

Gao, L., Zhai, Y., Ma, H., \& Wang, B. (2009). Degradation of cationic dye methylene blue by ozonation assisted with kaolin. Applied Clay Science, 46, 226229. https://doi.org/10.1016/j.clay.2009.08.030

Hao, O. J., Kim, H. \& Chiang, P.-C. (2010). Decolorization of Wastewater. Critical Reviews in Environmental Science and Technology, 30 (4), 449-505. https://doi.org/10.1080/10643380091184237

Jawad, A. H. \& Abdulhameed, A. S. (2020). Mesoporous Iraqi red kaolin clay as an efficient adsorbent for methylene blue dye: Adsorption kinetic, isotherm and mechanism study. Surfaces and Interfaces, 18, 100422. https://doi.org/10.1016/j.surfin.2019.100422

Jawad, A. H., Abdulhameed, A. S. \& Mastuli, M. S. (2020). Acid-factionalized biomass material for methylene blue dye removal: a comprehensive adsorption and mechanism study. Journal of Taibah University for Science, 14 (1), 305-313. https://doi:10.1080/16583655.2020.1736767

Jawad, A. H., Abdulhameed, A. S., Yaseen, Z. M., \& Malek, N. N. A. (2020). Statistical optimization and modeling for color removal and COD reduction of reactive blue 19 dye by mesoporous chitosan-epichlorohydrin/kaolin clay composite. International Journal of Biological Macromolecules, 164, 4218-4230. https://doi:10.1016/j.ijbiomac.2020.08.201

Mall, I. D., Srivastava, V. C., \& Agarwal, N. K. (2006). Removal of orange - G and methyl violet by adsorption onto bagasse fly ash- kinetic study equilibrium isotherm analyses. Dyes and pigments, 69, 210-223. http://dx.doi.org/10.1016/j.dyepig.2005.03.013

Medri, V., Papa, E., Mor, M., Vaccari, A., Natali, Murri, A., Piotte, L., \& Landi, E. (2020). Mechanical strength and cationic dye adsorption ability of metakaolin-based geopolymer spheres. Applied Clay Science, 193, 105678. https://doi.org/10.1016/j.clay.2020.105678

Meigoli Boushehrian, M., Esmaeili, H. \& Foroutan, R. (2020). Ultrasonic assisted synthesis of Kaolin/CuFe2O4 nanocomposite for removing cationic dyes from aqueous media. Journal of Environmental Chemical Engineering, 4, 103869. https://doi.org/10.1016/j.jece.2020.103869

Moore, D. M. \& Reynolds, Jr. R. C. (1989). X-Ray Diffraction and the Identification and Analysis of Clay Minerals. Oxford University Press, Oxford, 179201.

Mustapha, S., Tijani, J. O., Ndamitso, M. M., Abdulkareem, A. S., Shuaib, D. T., \& Mohammed, A. K. (2021). Adsorptive removal of pollutants from industrial wastewater using mesoporous kaolin and kaolin/ $/ \mathrm{TiO}_{2}$ nanoadsorbents. Environmental Nanotechnology, Monitoring \& Management, 15 (3), 100414. https://doi.org/10.1016/j.enmm.2020.100414

Nallis, K., Katsumata, K., Isobe, T., Okada, K., Bone, P., \& Othman, R. (2013). Preparation and UV-shielding property of $\mathrm{Zr}_{0.7} \mathrm{Ce}_{0.3} \mathrm{O}_{2}-\mathrm{kaolinite}$ nanocomposites. Applied Clay Science, 80-81, 147-153. https://doi.org/10.1016/j.clay.2013.06.004

Nandi, B. K., Goswami, A. \& Purkait, M. K. (2009). Adsorption characteristics of brilliant green dye on kaolin. Journal of Hazardous Materials, 161 (1), $387-$ 395. https://doi.org/10.1016/j.jhazmat.2008.03.110

Pereira, M. F. R., Soares, S. F., Orfão, J. J. M., \& Figueiredo, J. L. (2003). Adsorption of dyes on activated carbons: influence of surface chemical groups. Carbon, 41 (4), 811-821. doi:10.1016/S0008-6223(02)00406-2

Rocha, L. N., Barbosa, A. S., \& Rodrigues, M. G. F. (2016). Remoção do corante vermelho BF-4B em sistema descontínuo utilizando argilas esmectíticas. XI Encontro Brasileiro de Adsorção.

Rodrigues, D. P. A., Tomaz P. F., Barbosa T. L. A., \& Rodrigues M. G. F. (2018). Síntese de estrutura metalorgânica ZIF-8 e aplicação na remoção de corante reativo azul BF-5G. In: $1^{\circ}$ Simpósio de Química do CCA/UFPB, Areia.

Rodrigues, D. P. A., Tomaz, P. F., Barbosa, T. L. A., Barbosa, A. S., \& Rodrigues, M. G. F. (2018). Remoção do corante reativo azul BF-5G utilizando zeólita $\mathrm{NaY}$ modificada com brometo cetiltrimetilamônio. In: $1^{\circ}$ Simpósio de Química do CCA/UFPB, Areia.

Russel, J. D. \& Fraser, A. R. (1994). Clay Mineralogy: Spectroscopic and Chemical Determinative Methods. Springer Netherlands.

Salleh, M. A, M., Mahmoud, D. K., Karim, W. A. W. A., \& Idris, A. (2011). Cationic and anionic dye adsorption by agricultural solid wastes: A comprehensive review. Desalination, 280, 1-13. https://doi.org/10.1016/j.desal.2011.07.019

Silva, Ê. H. dos S., Rodrigues, D. P. A., \& Rodrigues, M. G. F. (2019). Adsorção em batelada de corante reativo azul bifuncional 5G em carvão ativado comercial. In: 4 Congresso Nacional de Pesquisa e Ensino em Ciências CONAPESC, Campina Grande. http://editorarealize.com.br/editora/anais/conapesc/2019/TRABALHO_EV126_MD1_SA6_ID1508_30072019172642.pdf

Singh, H., Chauhan, G., Jain, A. K., \& Sharma, S. K. (2017). Adsorptive potential of agricultural wastes for removal of dyes from aqueous solutions. Journal of Environmental Chemical Engineering, 5, 122-135. https://doi.org/10.1016/j.jece.2016.11.030

Tang, Q., Tang, X., Li Z., Chen, Y., Kou, N., \& Sun Z. (2009). Adsorption and desorption behaviour of Pb(II) on a natural kaolin: equilibrium, kinetic and thermodynamic studies. Journal of Chemical Technology \& Biotechnology, 84 (9), 1371-1380. https://doi.org/10.1002/jctb.2192

Vimonses, V., Lei, S., Jin, B., Chow, C. W. K., \& Saint, C. (2009). Adsorption of congo red by three Australian kaolins. Applied Clay Science, 43 (3), $465-$ 472. https://doi.org/10.1016/j.clay.2008.11.008 
Research, Society and Development, v. 10, n. 12, e13101220035, 2021

(CC BY 4.0) | ISSN 2525-3409 | DOI: http://dx.doi.org/10.33448/rsd-v10i12.20035

Wang, H., Li, C., Peng, Z., \& Zhang, S. (2011). Characterization and thermal behavior of kaolin. Journal of Thermal Analysis and Calorimetry, 105, 157-160. https://doi.org/10.1007/s10973-011-1385-0

Zhang, X., Lin, S., Lu, X. Q., \& Chen Z. L. (2010). Removal of Pb(II) from water using synthesized kaolin supported nanoscale zero-valent iron. Chemical Engineering Journal, 163, 243-248. https://doi.org/10.1016/j.cej.2010.07.056

Zhou, C., Gao, Q., Luo, W., Zhou, Q., Wang, H., Yan, C., \& Duan, P. (2015). Preparation, characterization and adsorption evaluation of spherical mesoporous Al-MCM-41 from coal fly ash. Journal of the Taiwan Institute of Chemical Engineers, 52, 147-157. https://doi.org/10.1016/j.jtice.2015.02.014

Zhou, y., Lu, J., Zhou, Y., \& Liu, Y. (2019). Recent advances for dyes removal using novel adsorbents: A review. Environ Pollut, 252, 352-365. https://doi.org/10.1016/j.envpol.2019.05.072

Zhu, H.-Y., Jiang, R., \& Xiao L. (2010). Adsorption of an anionic azo dye by chitosan/kaolin/ $\gamma-\mathrm{Fe}_{2} \mathrm{O}_{3}$ composites. Applied Clay Science, 48 (3), $522-526$ https://doi.org/10.1016/j.clay.2010.02.003 